\title{
The Impact of Intangible Assets on Firms Earnings Profitability: Evidence from the Athens Stock Exchange (ASE)
}

\author{
Gkinoglou Emmanouil Ph.D. \\ Tax and Business Consultant \\ Accountant, Greece \\ Ginoglou Dimitrios Ph.D. \\ Professor, Department of Accounting and Finance \\ University of Macedonia, Greece
}

\begin{abstract}
The present paper examines the effects of intangible assets in the return on equity and return on assets during the period from the begging of adopting International Accounting Standards (IAS) on financial statements and before the start of the Greek economic crisis. At this paper, is trying an effort for the contribution of the Intangible Assets as a very important part of the assets of the company but still "unmeasurable", but definitely main account for future gains. In this research study, using a dataset of Greek listed firms in the Athens Stock Exchange (ASE) is made an attempt to investigate the hypothesis that the firms that have large intangible assets have better return on equity and better return on assets for the Greek listed companies, during the period $2004-2009$, the most significant business period for the entire greek economy and especially for the listed greek companies in the Athens Stock Exchange (ASE), just before the start of the catastrophic Greek crisis. In conclusion, this study indicates that there are accounting and auditing problems of defined, measured and disclosed intangible assets to users of financial statements. Despite these problems the importance of intangible assets will increase, as the market grows and there is a constant need to supply reliable accounting information.
\end{abstract}

Key Words: Accounting, Intangible Assets, International Accounting Standards, Earnings Profitability, Intellectual Capital, Greece

\section{INTRODUCTION}

Like in any other field of research, attempting to give a specific definition of the dimension of intangible assets is especially difficult. Result of the complexity of the angle from which any special approaches the issue but rather the goal is that each researcher through the research work and results which aims to give a multidimensional concept topic on the concept of intangible assets. In literature, several proposals were made, different approaches were followed and tons of ink spilled in conferences, workshops, scientific papers, scientific books and several authors, scientists have attempted to address this issue.

Sometimes trying to give a precise and clear definition, many articles ended descriptive to work around a definition, referring to the categories in which separated the intangible, but not proposed anything specific. The question "What is intellectual capital and what is intangible, often replaced with the question" What classes can be divided intangible and intellectual capital? ". This shows the distraction from the goal of a specific, clear and descriptive understood definition. It seems more difficult to strive for a definition of the characteristics that we know what is really those intangibles that we face and subsequently to approach the elements that compose. It is easily to find and specify an intangible resource than to describe the total subject of intangibles. 
Such diversification helps to classify in a hierarchical order, starting from the general to the particular intellectual capital at the top, synonymous with the intangible and intangible assets (Intangible Assets), to be a part of the intangible capital.

Under the terms of consultants on the issues of Intellectual Capital, companies must measure and disclose and reflect on their financial statements and the relationship between the rights of intangible capital and financial performance of the company, translating changes to these rights as indicators of financial performance. Recognition therefore these additional elements that create value and increased business performance should be valued and recognized, but generally they provide complete and comprehensive information for users of these financial statements, whether internal or external users of these situations.

\section{THE INTANGIBLE ASSETS OF THE COMPANY}

The intangible capital, the intangible assets of the business are not something new that debuted recently on business needs. While it was still in operation and in the strategic business planning, though only in the last 20 years, since the mid-'90s began to draw the attention to the highly academic and professional Accountants Community-Business Consulting Financial Services. One of the problems it seeks to solve is the asymmetric information that comes to users of Financial Statements of Business by the Shareholders until the third dealing with the Company (Banks, Suppliers, and Customers). This information on the intangible assets of companies does not fully reflected in financial statements published by the Company. Thus there is no information on an essential and very important part of the assets of the company. The intangible capital.

What differentiates today business is the intangible property, rather than material assets. The mere possession of plant, machinery, transport equipment, raw materials and goods is not sufficient to ensure continued growth and profitability. Neither the low cost of raw materials is enough to the profitability of a company. No intangible assets, that remaining in business is the ability to mass produce a product or build things for others. This naturally keeps the company in a mediocrity on the state of the market and annual earnings. Only a well established brand, know-how, or other intangible assets can relieve the body from the mediocrity and / or extinction.

What differentiates that two similar, competing enterprises operating in the same sector, trade or productivity in the same area with similar providers and similar quality of the product is neither plant nor the administration buildings or machinery, or modes, or products. What differs the two companies, in the consumer's mind and choice, it is the intangible capital of firms, all these words which are the property of each company, there are also assessed more often in the company's accounts, but they offer to each firm's competitive advantage, being offered the chance to choose its own product by consumers, compared with competitors.

A typical example is the product of the mobile phone in the modern era and in the immediate past. Thus materials recombine in such a way as to give the mobile phone more technological capabilities Although a simple, everyday phone consists of the same quantity of raw materials with a phone built before five years (iron, plastic, silicone), these materials are used in such a way today to make the modern phone 30 times more potent, great utility and hence value. So this, added to the product to give more value and features are the intangible capital of the producing company.

Therefore, the bet required to win every business is how to acquire or develop or activate the hidden and intangible assets, to diversify and make it attractive to potential, future customer's 
own product to the competitive one.

\section{SOME DIFFERENT PROPOSALS - APPROACHES}

For one so relevantly new point it makes sense that there are different approaches and different treatments by many scholars and practitioners- economists of the audit and accounting profession. Thus, different interpretations are found in the international literature to address the same issue.

Some of the terms used in the recognition and interpretation of the dormant assets of the company are Intangible Assets, Intellectual Property, Intellectual Assets , Intellectual Capital, Knowledge Based Assets, Knowledge Capital e.t.c.

\section{LITERATURE REVIEW}

As mentioned above, this intangible property of companies, does not appear suddenly. He was always there, just never been good looking and measurable and have never attempted to measure the property, let alone to manage the business these resources by offering a competitive advantage. The effort that intensified in the last 20 years, by trying to become even more pronounced after 2000 .

So, we can distinguish two periods in which the original proposals were expressed, processed, corrected and reconciling as well as proposals for measurement models. These periods are before 2000 and after 2000 .

An initial approach by Edvinsson and Malone (1997), is the use of the terms of intangible capital and intangible assets. The definition given is that "intangible assets are those which have no physical existence, but also contribute to the value of the firm. Already recognized by a first attempt to interpret that the main characteristic is the lack of physics - physical existence, and even non-physically contribute to the creation of value of the company. This approach is a first attempt at classification of intangible assets. So, according to them "the intangible capital is the human and structural capital". Since then, many different classification efforts were made by many academics and even more specific, business economist profession. Different efforts, different proposals, according to the optical prism through which every author considered the effect of intangible assets and depending on the objective which focuses each.

The terms spiritual or intellectual capital, Intangible and intangible assets, occur very frequently in the literature. Depending on the point of attending every author, this property of the company, use, analyze and work around the definition. But it is not synonymous definitions of the same. More likely it seems that dimension, it is a bit-part of another.

The term intellectual capital, derived from the literature of the science of Human Resources, while the term intangible, from the science of accounting. The consequence of all this is the term intangible asset, is more restrictive criteria and refers to the recognition of those assets from your existing accounting system, but usually covers the widest range and all aspects of the greater whole called the Cultural Capital (Intellectual Capital), concluding that intellectual capital includes all types of intangible. Below, the different tests and different types of intangible capital as proposed during the years analyzed, indicating the contribution of each proposal in the science of identification, measurement and contribution of intangible assets to the value of each company. 
Especially in recent decades, intellectual property intellectual business was discussed between many chairman of the board, financial advisors and consultants, directors and the accountants.

In another attempt the same year, Sveiby (1997) defines the intangible asset, in his intangible asset monitor, through its division into three categories, which stem from the staff of an organization.

Stewart (1998), treats intellectual capital as an intellectual material (knowledge, information, intellectual property, expertise) that can together collectively be used to create value. This is recognized as a collective intellectual knowledge. Bontis et al (1999), use the term intangible sources, and recognize the category of intangible resources such intellectual capital. Therefore define the intellectual capital as the set of intangible resources and inputs generated, and their intangible sources, interpreted by each factor that contributes to the overall value of a business process.

As mentioned above, the attempt to define the assets of that company, has begun intensively in the mid 90s, but culminates in the new millennium. Thus, the greatest explosion of interest in the issue of intangible assets of companies, culminating in this first decade, during which, most articles were written so they can disclose, what really lies and that really because most of the value of current operations.

The moment developed is not random. The last decades after the second worl war, the economy going through the management revolution, in which companies use the knowledge to improve their competitiveness. Increasingly, that is, companies realize the role of knowledge in business, recognizes the strengths, its competitive advantages of each, and the points and win the others, they are not visible, or their competitors; or those directly involved (ownership, customer trading).

At the dawn of the new millennium, the selection of companies to seek ways to develop and evaluate the intangible property, shows the growing interest exists for this issue. A new attempt to approach and interpretation of the matter is by Sanchez et al (2000), who provided intangible, differentiate their intangible resources, which can be measured at a given moment and intangible activities arising during a period of time.

It is obvious that over the years and close to today, the interpretations given, reaching more financial dimension, ie an interpretation of some assets of the company, which circumstances can turn a profit for the company, either directly or supporting the broader function of the operation aiming at profit.

Sullivan (2000), provides the mental - intellectual capital as the knowledge that, under certain conditions, can be turned into profits for a company, while Lev (2001) provides that intangible assets of the company, is a cause for future profits, which have no physical (material) or financial status (ie excluding shares or bonds financial status. Gu and Lev (2001), define five different areas of intangible assets, research and development, advertising, cost of capital, information systems and technology assets.

Several times, various attempts to define by academics, rather than end up defining "what is the intangible assets of the business" definition "What are intangible assets. Or that there is a material asset, thereby classifying the intangible. So much effort, and ended up in what is named "material asset" for business. Upton (2001), refers to non-financial disclosures, indicators, ratios, and other information not presented in the basic financial statements and 
intangible assets, which are elements of the company which is neither financial nor material which can not be regarded as assets, but it is important to the success of the company. As a non-physical - physical factors that either contributed or used to produce goods and services businesses, expected to provide future benefits for the company that uses these factors recognize the intangible (Blair and Wallman, 2001). Petty and Guthrie (2000), recognize intellectual capital as the economic value, two categories of intangible assets of an enterprise, human and organizational capital, while Ordonez (2003) give a broad concept of intellectual capital as the difference between the market value of the company and the book value. Are the sources, based on knowledge, contribute to a competitive business advantage from intellectual capital.

\section{ATTEMPTS TO CATEGORIZE}

After trying to decide on the appropriate definition of an intangible, the problem of categorization or separation and the division into similar groups. As expected, following a variety of definitions, numerous efforts and proposals made for a different classification and different approaches tried to explain more fully the same issue.

A first approach, which followed and which influenced so many writers is that of Edvinsson and Malone (1997), who set the intangible capital as a synthesis of human and physical Structural, Organizational Capital. Sveiby's proposal (1997), was the separation of intellectual capital in the core competencies of workers, internal structure and external structure. According to Sveiby, the development of intellectual capital based on the core competencies of workers.

But the majority views of researchers were directed to the separation of intellectual capital into three categories. There were just different views concerning the naming of these categories. So others were named creativity, knowledge and identification of other units (Granstrad 1999), structural and Human Relations with third parties (Canibano et al , 1999), internal and external structure of human capital (Brennan and Connell, 2000 ), (or in other capacities of employees - Gunther, 2001) or the human, organizational, operational and customer capital (Mouritsen et al ,2002)

As seen, the majority of researchers, writers, propose the separation of intellectual capital in three categories human - structural and relations to third parties. Finally, these categorizations do not give a clear definition, despite living in a misty. They offer a clear perspective and guidance for proper and safe management of intangibles. Also not clearly defined what assets and resources belonging to each category.

Lev (2001), accept the non physical structure for the intangible adding also the non - monetary substance. Gu and Lev (2001), found that investment in research and development costs (a special intangible category), advertisement, trademarks and technological improvement leads to higher market value for the company.

Finally, the majority of the research agree that is very difficult to identify the intangible assets with a clear and specify definition and usually must be described in generally (Edvinsson \& Malone, 1997, Stewart and Ruckdeschel, 1998, Bontis et al.,1999, Lev, 2001, Sullivan, 2000, Sanchez et al., 2000, Ordonez de Pablos, 2003). The majority of the proposals suggest that the intangible assets have non-physical existence (Edvinsson \& Malone, 1997, Steward, 1998, Blair \& Wallman, 2001, Lev, 2001), contribute in the market value of entity (Edvinsson \& Malone, 1997, Petty \& Guthrie, 2000, Sullivan, 2000, Lev, 2001, Gu \& Lev, 2001) and also have a 
significant effect in the future profits of company (Edvinsson \& Malone, 1997, Stewart, 1998, Blair \& Wallman, 2001, Lev, 2001). However, although the disagreement for recognition as an asset for the company, nevertheless agree that the owner is the company and the final goal is the growth, and the effect in the future profits (Upton, 2001).

\section{THE HIDDEN FORTUNE OF THE COMPANY}

As it is common belief, the major strategic factor for the excessive earnings for a company, is "something" that it is still unmeasurable yet. It is something hidden that create the fortune, the value for the company. Below follows a statement (Seetharaman et al, 2003) of what can be recognized as intangible assets or intellectual capital, which are identifiable, can be moved and changed their ownership, with some life, detached from the daily work of the owner.

So we can, depending on the type of activity of each company to recognize the following missing features, lacking physical existence, deprived of representation in the financial position statements, operators of the business, unaware that they are held, but often is what gives a competitive advantage and the special expertise of the company, making it stronger, stiffer competition between:

- Drafts

- Distribution Network

- Libraries

- Brand

- Emission Permits

- Purchase and sale agreement

- Chemical Formulas

- Computer Software

- Electronic Databases

- Contracts

- Cooperation Agreements

- Copyright

- Customer lists

- Contracts with customers

- Relations with customers

- Drawings

- Production rights

- Distribution Rights

- Drilling rights

- Contracts with employees

- Mechanical Drawings

- Environmental Rights-of emission rights

- Film

- Recipes cooking

- Franchise agreements (Franchise)

- Historical Documents

- Expert Knowledge (Know How) in terms of production, organization, technology, etc.

- Loan Portfolio

- Manual databases

- Manuscripts

- Medical records and maps

- Rights for mining

- Musical Compositions 
- Natural Resources

- Patents

- Licenses

- Finance Portfolio Securities

- Shareholders Agreements

- Supplier Contracts

- Trademarks and Trade Names

- Trade Secrets

- Manuscripts Education

- Use of air rights, water, soil e.t.c

All these relate to specific kinds of intangibles that take part in certain types of businesses. A proposal on what could, under certain conditions, be recognized as a company's assets. It is not binding. It is true that many sub-sectors of the economy, they lack many of these resources, and is particularly important, other resources that are not listed in that list. For example, a sports club, or a particular SA, or Football or basketball or another sport, which makes a champion is for profit, people who have invested in it, it is clear that the primary and basic capital which founded and to which shareholders are investing early fans that support the team, players, the coaching group etc. which is not explicit and not specifically proposed in the above list.

\section{CATEGORIES OF INTANGIBLE ASSETS STRATEGIC SIGNIFICANT FOR BUSINESS}

In a broad sense, that the contribution of this hidden fortune, neither appears nor is counted but not shown adds value to the business and to support the view of the strategic importance of such intangible elements in the value of the business, we can discern additional categories. The existence of these groups in the economic environment of the company contributes to smooth operation, thus contributing to creating a good overall climate. On a good working environment, the company pays the most, and this yield translates to higher quality, better customer service in every respect, reducing loss or physical damage-or-better financial arrangements and other elements that make the company competitive. In the broad view, therefore, can be distinguished as a contribution to maximize its performance, good working relations with the government or other organizations. The professional conduct of the business to third parties creates confidence in and around the enterprise. A good working environment, could also be the basis for building competitive advantage in business. The term "good workplace" defines the attitudes of both management to the workers and employees together.

Could be distinguished with respect to relations of command - employee factors such as fair and equal treatment, a reward depending on the objective value and offer their respect for the personality of each participant in the life of the enterprise at any level of interest of management for all employees not as assets but as people, fine buildings and excellent technology with excellent hygiene, security, as far as possible, safety at work, both in performance and lasting security to work, etc.

All these contribute to creating a good working environment, which enhances the reputation of the company and contributes to productivity and quality of products and services. So while the individual (equal treatment, fairness, respect, solidarity, security, sanitation, etc.) may not be separate intangible assets of the company, it does not meet the above conditions for recognizing a fixed asset, however, help to consolidate other copyright - intangible assets such as goodwill, contracts with customers, customer lists, know-how etc. 
Another factor is the concept of knowledge, which confers a competitive advantage. The modern business and economic environment in which enterprises operate, requires the use of knowledge not only on parts of the company (distribution channels - Customers-market marketing, etc.) but the whole enterprise. This knowledge is embedded in the systems used and the skills and the key advantages of its executives. So the challenge facing firms is to develop mechanisms capable of detecting and following the administration of this particular knowledge in the plant, to increase the value of (Knowledge Management).

\section{CONTRIBUTION OF INTANGIBLE ASSETS}

Almost all investors and academia and business, all agree on the contribution of intangible assets, the value of the company. It is commonly accepted that high profits, the net return on investment by developing quickly, are some of the important features for successful investments. Few investors, however, recognize and analyze the intangible assets as factors leading to revenue growth and attain the company, according to others for profit (for-profit units) or otherwise maximize the value of the company.

Earnings above the average, from the proper management of intangibles because they contribute to cost savings through production or through the primary market price. These companies have earnings in excess of normal, compared with the average, are those owning or in possession or power of their valuable assets.

With the use of intangible assets, the company can benefit from a higher price, gaining market share, securing money without regard to whether the product is ordinary.

Examples of the patent, the use of which the company can save labor resources or raw materials during the manufacturing process. The brand is also relevant example. Many products are in the same format, similar almost the same features mostly the same packaging, same or similar quality, but the price is dramatically different, not because some companies have cost more to produce, because they use expensive materials but because the package is brand. The brand that the consumer is connected with memories of his own, personal system of values is ranked in the highest quality products, giving more satisfaction from the use, consumption, which means the willingness to pay higher prices to acquire the consumer, but higher profits for the company. Thus, without primary intrinsic value of the product is not spent to cover campaigns to enhance brand (especially for commercial products have established a specific brand name eg Lacoste, Ralph Laurent, etc.). Therefore, the major amount of the final retail price, an additional profit of the company (excessive earnings, the interpretation given by scholars to detect intangible assets). Other intangible may be having a large and qualified distribution network of business which can supply its products directly to major intermediaries in the chain (wholesalers).

Like all other fixed assets of a company, so the brands and all the intangible assets can grow and produce profits if the company funds available for promotion, advertising, research and renewal of technologies used. So we need to invest in the company to deliver the specific asset. If a business is reduced for one year the advertising costs that would improve the situation of the operating results, showing higher profits. But long term there will be problems in profitability and market share held by the company. Similarly in the field of technological development and expenditure on research and development. However, if a company that is wrong and reputation destroyed, material assets, and still have pretty good economic value, while at the same time, intangible assets, lose value very quickly.

The strategies followed by companies are often more efficient exploitation of intangible assets 
as mergers, acquisitions and the sale of the entire enterprise.

\section{METHODOLOGY}

In this research study we collect data from enterprises in ASE and using the base of data of Hellastat on period $2004-2009$ we drew data for 254 companies and the financial ratios for five period years the action of which negotiates in the ASE. Companies that were excluded of our data are those of the financier sector.

More specifically, the financing elements which we drew for every company were following: a) Total of Asset, v) Return on Equity Before Taxes, c) Return on Assets Before Taxes,

The specific period, starts from the adoption of the International Accounting Stantards from the Greek listed companies in the Athens Stock Exchange at 2004. The last year of the study (2009), is the previous year from the start ofd catastrophic greek economic crisis. At 2010, the new Greek Prime Minister, announce that the greek debt is huge, greater than the previous annual reports. For this reason, the greek government ask the assistance of the International Monetary Fund (IMF). From this year (2010) and until now, the greek economy, is under supervision of International Monetary Fund and European Committee and until today, the greek crisis seems not to finish. That is the reason for the research period 2004-2009. Future research, will be focused in the period during the crisis, (2010-20XX) comparing the results from the previous period (2004-2009) to the crisis period.

Our Objective is to investigate how much the companies with higher total of asset achieve higher efficiency of proper funds or globally invested capital.

For this reason, we created two teams with base the total of asset. Using the median we separated the companies in the (Team A) with total of asset bigger/equal from 84.773.514 Euros and them (Team B) with total of asset smaller than 84.773.514 Euros.

In this survey the sample that was used are firms listed on the Athens Stock Exchange and were divided into two groups, those that have large fixed assets and those that have less fixed assets and assumed that those with higher fixed assets null hypothesis $\mathrm{H}_{0}$ will have greater intangible assets hypothesis $\mathrm{H}_{1}$ and will be verified by financial ratios

\section{CONCLUSIONS OF OUR RESULTS}

From the next table I (statistical results) we can see for the first group A the mean price for ROE is $10,56 \%$ while the mean price for ROE for the second group B is $-2,97 \%$. Further more the mean price for $\mathrm{ROA}$ is $3,85 \%$ while for the second group B the mean price for ROA is $0,27 \%$ 


\section{Group Statistics}

\begin{tabular}{|ll|l|l|l|l|}
\hline & $\mathrm{E}$ & $\mathrm{N}$ & Mean & Std. Deviation & $\begin{array}{l}\text { Std. Error } \\
\text { Mean }\end{array}$ \\
\hline ROE & $>=$ & 719 &, 1056 & 1,17574 &, 04385 \\
& $\begin{array}{l}84773514,00 \\
<84773514,00\end{array}$ & 714 &,- 0297 & 1,44995 &, 05426 \\
\hline ROA & $>=$ & 697 &, 0385 &, 12351 &, 00468 \\
& $\begin{array}{l}84773514,00 \\
\end{array}$ & & & & \\
& $<84773514,00$ & 681 &,- 0027 &, 20897 &, 00801 \\
\hline
\end{tabular}

\section{Table I : Descriptive statistics of the two groups}

The critical point that we want to check is that if the mean of both groups are different. So that our hypothesis becomes as follows:

$\mathrm{H}_{\mathrm{o}}: \mu_{1}=\mu_{2}$

$\mathrm{H}_{1}: \mu_{1} \neq \mu_{2}$

Where $\mu_{1}$ is the mean for the ratio ROE or ROA for group $\mathrm{A}$

And $\mu_{2}$ is the mean for the ratio ROE or ROA for group B

Our analysis use the SPSS 19 statistic programmed and we also use the t-test analysis

The statistical results are showed in table II

Independent Samples Test

\begin{tabular}{|c|c|c|c|c|c|c|c|c|}
\hline & \multicolumn{2}{|c|}{$\begin{array}{l}\text { Levene's Test for } \\
\text { Equality of } \\
\text { Variances }\end{array}$} & \multicolumn{5}{|c|}{ t-test for Equality of Means } \\
\hline & & $\mathrm{F}$ & Sig. & $\mathrm{t}$ & $\mathrm{df}$ & $\begin{array}{l}\text { Sig. (2- } \\
\text { tailed) }\end{array}$ & $\begin{array}{l}\text { Mean } \\
\text { Difference }\end{array}$ & $\begin{array}{l}\text { Std. Error } \\
\text { Difference }\end{array}$ \\
\hline ROE & $\begin{array}{l}\text { Equal } \\
\text { variances } \\
\text { assumed } \\
\text { Equal } \\
\text { variances not } \\
\text { assumed }\end{array}$ & 2,114 & ,146 & $\begin{array}{l}1,940 \\
1,939\end{array}$ & $\begin{array}{l}1431 \\
1368,642\end{array}$ & 053 & $\begin{array}{l}13526 \\
, 13526\end{array}$ & $\begin{array}{l}, 06971 \\
, 06976\end{array}$ \\
\hline ROA & $\begin{array}{l}\text { Equal } \\
\text { variances } \\
\text { assumed } \\
\text { Equal } \\
\text { variances not } \\
\text { assumed }\end{array}$ & 2,504 & ,114 & 4,467 & 1098,392 & ,000 & ,04120 & ,00927 \\
\hline
\end{tabular}

Since Levene's test to test for the hypothesis of gender variation for the 2 groups we observe that for both indicators ROE and ROA, the p-value (Sig.) is greater than 0.05 , therefore, assume gender variations and standard deviation and so on t-test will use the first line

For the ROA ratio p-value for testing the equality of the two means are equal to zero (Sig. (2tailed)). 
Thus the null hypothesis is rejected, ie the mean average of the two groups differ significantly in terms of statistical significance $a=5 \%$. It shows that companies with high asset has a higher return on total invested capital compared to companies with less than total assets.

However, the index ROE p-value for testing the equality of the two means are equal to 0.053> 0.05 when the null hypothesis is not rejected at the level of significance $a=5 \%$.

However, it is rejected for the level of significance $\mathrm{a}=10 \%$.

\section{CONCLUSION}

Ultimately, the issue of intangible assets is a daily preoccupation for companies. The measurement and management of intangible assets is not easy and is not in the same way with the materials. From empirical research shows that traditional industries such as aerospace, defense and oil have long and strong presence of intangible assets. It could be an element of future research to compare the relationship between intangible both traditional heavy industries and new industries such as multimedia industry. Although the research field, it seems to lack an internationally accepted language of communication, though the investigations are at a good level to determine the target (intangibles) and other data relating to them. Numerous articles, opinions, have written a general interest has been expressed for the understanding by all parties with business parties (managers, accountants, academics, consultants, etc.) of those intangible elements of the business.

The paradox facing economic practice, despite inconclusive scientific definition of the matter is that the more the financial system and businesses rely on intangibles and intellectual capital, both become more powerful, since these resources are the key building blocks for growth and value creation. Certainly the more intense investment in intangible resources do companies and the overall financial system, the more vulnerable it is.

Our analysis shows that there are few examples of empirical research and the literature, there is a lack of theoretical framework which could be demonstrated in practice. Absent that, a specific definition of intangible and intellectual - intellectual capital while the division into three categories, is not satisfactory.

It is obvious the lack of a practical approach to the issue of intangibles, which could provide information and assistance to businesses. In future research, could be investigated various topics such as concrete objectives of the research on intangible parallel proposals for the management of these intangible factors, proposals for exploitation and utilization in practice the information obtained from the study of intangible rather than we are left only to identify their examination of the application or not in practice, theories are developed, focusing on specific aspects of other intangible knowledge, development of theoretical underpinnings and workable in practice regarding the management of this property of enterprises, generalized measurement model which can express, to reflect and include all sorts of intangibles that may be held by the company, whether it means developing a new model or optimize an existing one.

Examining empirical results from the Athens Stock Exchange, for the greek listed companies for a 5-year period, after the adoption of the International Accounting Standards (2004-2009), and before the greek economic crisis effect the entire greek economy and many greek companies (SME's and listed), found that the companies with higher total of asset achieve higher efficiency of proper funds or globally invested capital and have also grater intangible assets at the level of significant $5 \%$ but not for level of significant $10 \%$. 
However, future research, may examine, whether or not the crisis period for the greek economy, affects the intangible assets and the total assets of the listed companies and also achieve higher efficiency of proper funds or globally invested capital, comparing to the previous period, that before crisis starts. Also, future research, can also compare, the financial statements after the adoption of International Accounting Standards with the period after the adoption of Greek Accounting Standards (ELP), from 01/01/2015 in Greece (adopting the EU Guide), for the listed companies.

Also important it was to work on practical implementation of empirical research to investigate whether and to what extent operational management of intangibles

In conclusion, we can see, how visible is their contribution to creating competitive advantage and thus maintain the company's high level of competition.

The next challenge for all stakeholders (shareholders, investors, employees, management, financial advisors, accountants - academics, etc.) is to identify and establish management procedures, measurement and imaging in increasingly Intangible-Based Economics Environment.

\section{References}

Blair, M. M., \& Wallman, S. M. H. (2001). Unseen wealth: The value of corporate intangible assets.

Bontis, N., Dragonetti, N. C., Jacobsen, K., \& Roos, G. (1999). The knowledge toolbox:: A review of the tools available to measure and manage intangible resources. European management journal, 17(4), 391-402.

Brennan, N., \& Connell, B. (2000). Intellectual capital: current issues and policy implications. Journal of Intellectual capital, 1(3), 206-240.

Canibano, L., García-Ayuso, M., Sánchez, P., \& Olea, M. (1999). Measuring intangibles to understand and improve innovation management: preliminary results. In International Symposium Measuring and Reporting Intellectual Capital: Experiences, Issues and Prospects. June. Amsterdam.

Edvinsson, L., \& Malone, M. S. (1997). Intellectual capital: The proven way to establish your company's real value by finding its hidden brainpower. Piatkus. p22

Granstrand, O. (1999). The economics and management of intellectual property, Edward Elgar Publishing, Cheltenham

Gu F.and Lev B.(2001), “Intangible Assets- Measurement, Drivers, Usefulness”, Working Paper, Boston University,/ New York University.

Gunther, T. (2001). Controlling Intangible Assets under the Framework of value-based management. Kostenrechnungspraxis No Sonderheft, 1, 53-62.

Lev, B. (2001), "Intangibles: Management, Measurement and Reporting", Bookings Institution Press,

Mouritsen, J., Bukh, P. N., Larsen, H. T., \& Johansen, M. R. (2002). Developing and managing knowledge through intellectual capital statements. Journal of intellectual capital, 3(1), 10-29.

Ordóñez de Pablos, P. (2003). Intellectual capital reporting in Spain: a comparative view. Journal of Intellectual Capital, 4(1), 61-81.

Petty, R., \& Guthrie, J. (2000). Intellectual capital literature review: measurement, reporting and management. Journal of intellectual capital, 1(2), 155-176.

Sanchez, P., Chaminade, C., \& Olea, M. (2000). Management of intangibles-an attempt to build a theory. Journal of intellectual capital, 1(4), 312-327.

Seetharaman, A., Lock Teng Low, K., \& Saravanan, A. S. (2004). Comparative justification on intellectual capital. Journal of Intellectual Capital, 5(4), 522-539.

Stewart, T., \& Ruckdeschel, C. (1998). Intellectual capital: The new wealth of organizations,1st edition , Nicolas Brealey Publishing, London

Sullivan, P. H. (2000). Value driven intellectual capital: how to convert intangible corporate assets into market value. 
Emmanouil, G., \& Dimitrios, G. (2017). The Impact of Intangible Assets on Firms Earnings Profitability: Evidence from the Athens Stock Exchange (ASE). Archives of Business Research, 5(8), 50-62.

John Wiley \& Sons, Inc., New York, NY, p.228

Sveiby, K. E. (1997). The new organizational wealth: Managing \& measuring knowledge-based assets. BerrettKoehler Publishers, San Francisco, CA.

Upton, W. S. (2001). Business and financial reporting. Challenges from the new economy. In Financial accounting series (FASB). Special report (219-A), 